\title{
Slow Fashion Trends: Are Consumers Willing to Change Their Shopping Behavior to Become More Sustainable?
}

\author{
Adrián Castro-López ${ }^{1, *}$, Victor Iglesias ${ }^{1}$ and Javier Puente ${ }^{2}$ (D) \\ 1 Economics and Business Faculty, Business Administration Department, Campus Cristo, University of Oviedo, \\ 33006 Oviedo, Spain; viglesia@uniovi.es \\ 2 Polytechnic Engineering Faculty of Gijón, Business Administration Department, Campus Viesques, \\ University of Oviedo, 33203 Gijón, Spain; jpuente@uniovi.es \\ * Correspondence: castroadrian@uniovi.es; Tel.: +34-985-10-55-87
}

Citation: Castro-López, A.; Iglesias, V.; Puente, J. Slow Fashion Trends: Are Consumers Willing to Change Their Shopping Behavior to Become More Sustainable? Sustainability 2021, 13, 13858. https://doi.org/10.3390/ su132413858

Academic Editors: Andrea Pérez and Eundeok Kim

Received: 10 November 2021 Accepted: 13 December 2021 Published: 15 December 2021

Publisher's Note: MDPI stays neutral with regard to jurisdictional claims in published maps and institutional affiliations.

Copyright: (c) 2021 by the authors. Licensee MDPI, Basel, Switzerland. This article is an open access article distributed under the terms and conditions of the Creative Commons Attribution (CC BY) license (https:/ / creativecommons.org/licenses/by/ $4.0 /)$.

\begin{abstract}
The fashion industry, despite generating great benefits in terms of trade, employment and income worldwide, is considered one of the most polluting industries due to the linearity of its production process with a high consumption of energy and raw materials as well as of waste generation. Furthermore, the short life cycles of its products, where the consumer seeks more to be fashionable than the products' durability, contribute to this. However, this paradigm is changing due to society's increased concern for the environment and a healthier way of life, promoting the emergence of a new concept called slow fashion, which seeks to improve the sustainability of fashion items from an environmental and ethical point of view. In this way, many companies are implementing circular economy measures in their production processes and innovating more circular products. The purpose of this work was to determine the consumer orientation toward slow fashion consumption, their perceived value and if they are willing to accept changes in their own behavior. The results confirm this new consumer orientation toward slow fashion consumption, which entails an important business transformation, fostering the innovation of new products and manufacturing systems characterized by a circular approach.
\end{abstract}

Keywords: slow fashion; circular economy; sustainable consumer; sustainability; product innovation

\section{Introduction}

The industrial revolution marked the beginning of fossil fuel consumption in production processes. In this period, industrial growth was considered a source of wealth and prosperity. However, at present, given the overexploitation of natural resources and the destruction of ecosystems, the scientific community shows warning signs of the possibility of ecological collapse, with important environmental and health problems that seriously concern society and international organizations. This scenario is undoubtedly linked to irresponsible management of resources, which puts social and economic capital at risk in the near future [1].

The fashion industry brings substantial benefits to the economy in terms of trade, employment, investment, and income throughout the world. Fashion products, determined by designers, cultural aspects, and creative industries, are subject to sudden and unpredictable changes by consumers that allow this industry to be characterized by the short life cycles and high differentiation of its products and changes in demand associated with prolonged and inflexible supply processes [2]. As a result of the mass production of these types of products, energy and raw materials are consumed in excess.

Within the European Union, fashion had 171,000 companies, employing 1.7 million people, and generating a turnover of 178,000 million euros [3]. In 2019, the fashion industry contributed $2.8 \%$ to GDP in Spain, $2.7 \%$ in France and $1.2 \%$ in Italy. In addition, households in the European Union spent about 264,000 million euros on clothing in $2018,10 \%$ more 
than in 2008 [4]. These amounts show the importance of the fashion sector in the European Union.

Nevertheless, the fashion industry is considered one of the most polluting industries in the world, after the oil industry, being responsible for $10 \%$ of the production of global $\mathrm{CO}_{2}$ emissions and $20 \%$ of global water waste [4]. In this way, millions of producers and consumers around the world are involved in value chains known as linear. These value chains imply an excessive consumption of energy and raw materials and a high production of waste, with little room for reuse or recycling. Moreover, Europeans buy an average of more than $12 \mathrm{~kg}$ of clothing per year, which represents a global consumption of more than 46 million $\mathrm{m}^{3}$ of water and 195 million tons of $\mathrm{CO}_{2}$.

To combat this waste, the European Commission has created a Circular Economy Action Plan that shows the way to move toward a neutral economy [5]. In addition, customers, concerned about this situation, are looking for new alternatives based on products that cause minimal environmental damage and generate a positive social impact, increasing awareness of both the negative impact of large supply chains and the care for sustainability by retailers [6].

The term "circular economy", introduced by [7], is based on a new economic paradigm in which the concepts of industrial and social evolution are developed considering sustainability in connection with a philosophy without waste. This circular economy model focuses on the principle of "closing the life cycle" of products, services, raw materials, and energy to make more efficient use of resources and to improve sustainability [8]. It is an economic model that involves stakeholders collaborating to maximize the use of raw materials to minimize natural resources and energy waste and generate a positive impact on the environment and society [1].

In line with the new circular economic model and in contrast to fast fashion-which allows companies to optimize their supply chain to respond quickly to new fashion trends and consumer demands by putting fashion products in stores with a delivery time of less than a month [9] - developed in the 1950s with the rise of prêt à porter, a new concept called slow fashion or sustainable fashion has emerged as an alternative of this sector to mass production and its consequences. The Spanish association of sustainable fashion defines it as "any garment or accessory that respects the environment, human health and workers, and promotes the use of sustainable materials, the reuse of existing materials and local production". This evolution in the fashion industry is an opportunity for a great transformation toward sustainability [10]. Additionally, it has been observed that health factors such as the COVID-19 pandemic have caused consumers to consider a new, more sustainable mode of consumption [11,12].

This new sustainable business model is driving consumers to look not only at the aesthetic aspect of fashion apparel but also at other ethical and environmental characteristics. For example, in the European market, $38 \%$ of consumers look at the social impact of the garment before purchasing it, and 37\% look at its environmental impact [13]. With this new scenario, companies in the sector are starting to develop alternatives in this direction. For example, Inditex's JoinLife, Mango's Committed or H\&M's Conscious collections aim to offer their customers ethically produced clothing with more sustainable fabrics, which customers can identify with accredited labels. In addition, 100\% sustainable companies are emerging, such as the company Ecoalf, which manufactures high-quality clothing from waste materials such as plastic bottles, fishing nets, recycled cotton, tires, etc.

Companies are aware of the need to take steps to improve their production processes and product quality, but are customers predisposed to accept the correlated new market conditions? This paper attempts to respond to this research issue. The purpose of this research is to analyze the fashion consumer behavior and her or his willingness to change to a sustainable fashion model in an attempt to answer the following questions: Are fashion customers predisposed to accept the new market conditions? Are they willing to pay more for a sustainable product? This paper focuses on fashion consumers in the Spanish market. 


\section{Theoretical Background}

Prêt-à-porter marked a revolution in the fashion industry, establishing fast fashion as a production and consumption model. Nevertheless, nowadays, the term "sustainability" in fashion emerges as a social response to the excessive production and consumption typical of the linear economic model known as fast fashion [14,15].

There are different terms that connect fashion and sustainability [16] such as ecological fashion, produced from green, organic and environmentally friendly products; ethical fashion, within the framework of fair trade, following non-exploitative principles and decent working conditions, and minimizing pollution in the production process [17]; and slow fashion, which focuses on slowing down the production and consumption processes, promoting sustainable values among all actors involved in the fashion system [18], and is part of circular economy [19-21]. In this paper, we focus on the last one.

\subsection{Slow Fashion Orientation}

Over the past few years, the fashion industry has negatively influenced the consumer's well-being by creating a feeling of artificial necessity, novelty and obsolescence [22,23] that are driven by mass production processes typical of the prêt-à-porter paradigm. In addition, some authors [23] affirm that fashion-oriented consumers look for the latest trends, and they are often less inclined to take environmental aspects into account in their decision making. Nevertheless, other authors [24-27] emphasize the society's concerns about environmental issues and how they are beginning to modify their consumption habits. Some studies [28] affirm that all consumers approach the "greenness" of their lifestyles and consumption practices in different approaches, as they are facing contextual influences at the micro (e.g., consumers' decision-making process) and macro levels (e.g., shifting social norms, increasing coverage, etc.). In this sense, sustainable clothing consumption is understood as the tendency of an individual to purchase and maintain clothing in a sustainable way $[23,29]$.

However, it has been indicated [30] that sustainability by itself will not be enough to make the necessary changes in consumers' apparel purchases due to three reasons: (a) the sustainability of clothing is too complex, (b) consumers are too diverse in their ethical concerns, and (3) apparel is not an altruistic purchase. Some authors [30] allude to a lack of understanding about ethics and sustainability and their relation to a sustainable product; a consumer's thinking is "I look good with these clothes", when it should focus on how that product was made [24], considering if it fulfilled all ethical standards. Some consumers consider slow fashion products as luxury products due to their price and exclusivity [31]. Nevertheless, nowadays, the gradual shift from fast fashion to a sustainable and socially responsible fashion is clearly visible around the globe [32]. Therefore, it is essential to understand the slow fashion orientation and how this influences the perceived value.

For this purpose, some authors [25] developed a scale capable of analyzing the dimensions (equity, authenticity, functionality, localism and exclusivity) that define consumer orientation toward slow fashion and how they influence the perceived value.

Hypothesis 1 (H1): The slow fashion consumer orientation influences the perceived value of sustainable products.

\subsection{Customer Perceived Value}

Customer perceived value is the consumer's overall assessment of the product's benefit [26]. Consumers make this evaluation by comparing the benefits that they receive (quality, comfort, etc.) with the cost (money, time, etc.) they must afford [33]. Consumer's perceived value is based on an evaluation of cost-benefit in comparison with other competitors in the market [34].

Traditionally, the concept of customer perceived value included the dimensions of price and quality, and later, the social and emotional aspects of value were added [35]. In 
this sense, the Customer Perceived Value Scale (CPVS) [36] analyzes perceived value in terms of four factors: quality (expected benefit of the product), price (cost of purchasing the product), emotional (feelings provided by the product) and social (expected benefit to improve their position in society) [24].

The consumption of fashion products is an effort by consumers to manifest their thoughts and feelings or the image they wish to be perceived by the society [37]. Between the 1950s and 1990s, consumers did not just buy products based on fashion and focus on aesthetics alone. However, nowadays, consumers are increasingly looking for products that meet certain environmental and ethical standards in their production and distribution. In addition, consumers put pressure on companies to incorporate socially and environmentally responsible practices in their production process [38] following the message that we should consume products that are sustainably produced and designed for longevity $[23,39,40]$. In this sense, many companies are trying to make their products more valuable [41] and thus have a more favorable position in the market to increase their profitability. For this purpose, they must not only offer valuable products from an aesthetic standpoint but additionally care about improving their production processes with the aim of ensuring the more sustainable nature of products and commitment to ethical and social values. This would improve the consumer's attitude toward their apparel products. Some literature [42] considers attitude as one of the key factors in consumer behavior, which plays an important role in purchase intent. Moreover, slow fashion products allow consumers to feel satisfied with their choice because they are purchasing a quality product that, beyond aesthetic aspects, meets environmental and ethical requirements too. These factors influence the consumer's attitude and therefore their purchase intention. In this way, it also differs from traditional fast fashion, increasing the emotional value of the product purchased. Sustainable fashion consumers are attached to their values and believe in them. Several studies $[27,43]$ confirm the positive relationship between attitude and consumer behavior through a sustainable perspective. For this reason, if the consumers perceive the sustainability value in fashion apparel, it is considered as an added value, they are willing to modify their behavior for environmental protection [44], and they will be more willing to buy it $[24,25]$.

Hypothesis 2 (H2): The added value of a slow fashion product increases the purchase intention.

\subsection{Willingness to Pay}

The price is always a key factor in the purchase decision process [44-46]. Willingness to pay (WTP) can be defined as "the affordable price for a product that a buyer is ready to pay" [47]. Products manufactured in a circular and environmentally and ethically sustainable way are usually more expensive than products that do not comply with these characteristics. Nonetheless, sustainable fashion products present a higher perceived value by consumers due to the perception about how these products help to protect the environment and the society [48]. In comparison with fast fashion consumers, the slow fashion consumers purchase less, and they concentrate mainly on the quality and serviceability of the garments [27] and perceive a higher overall value obtained from consuming these types of garments [48].

Thus, the positive satisfaction of customers toward this type of sustainable fashion product reinforces their loyalty, and, consequently, they are willing to pay more for their products [24], both because of the conscious estimation of value and because they feel better emotionally with that purchase.

Hypothesis 3 (H3): The sustainable fashion consumer is willing to pay more for slow fashion products.

In the following sections, we analyze the above assumptions. 


\section{Method}

To test the conceptual model along with hypotheses, we focused on the fashion market in Spain. To carry out this study, we conducted a qualitative and quantitative analysis through online surveys conducted among regular consumers of fashion garments and accessories in Spain. Afterward, a path analysis was used to determine the causal relationship between the different study variables to validate the hypotheses raised in the previous section.

\subsection{Data Collection}

To test the proposed conceptual model along with the hypotheses, an online questionnaire was disseminated to regular users who purchase fashion items (sustainable and non-sustainable). The sample population was Spanish nationwide residents, aged 18 years or older. The survey was conducted via social networks (mainly Instagram, WhatsApp, Facebook, and Twitter), email and personal interviews. To measure the research model, we employed validated instruments whenever available. In this way, the questionnaire was structured in five sections. The first section establishes questions to get to know the respondents' profile (age, gender, education, annual consumption of fashion products, etc.). The second section evaluates slow fashion orientation by adapting the [24] scale to this case. It consists of 5 variables (equity, authenticity, functionality, localism, and exclusivity) and 15 items that evaluate the orientation through the variables described above. The third section evaluates the perceived value by adopting the scale through 4 variables (quality, emotional, price and social) and 19 items that define these variables [36]. The fourth section assesses the purchase intention with 3 items and follows the scale proposed by some authors [26] for slow fashion consumption. Finally, the fifth section evaluates the willingness to pay more with 3 items and adopts some specific scales regarding the slow fashion consumption [26,49]. All the scales were measured following a seven-point Likert scale, ranging from 1 (strongly disagree) to 7 (strongly agree).

\subsection{Sample}

The questionnaire was distributed by the snowball method through social networks such as Facebook, Instagram, or WhatsApp. After filtering incomplete or invalid responses, we considered for this study 267 valid responses. Table 1 illustrates the main demographic information for the sample analyzed.

The survey results reveal that $65.2 \%$ of the consumers surveyed claim to follow fashion trends and do not go shopping for clothes very often, with more than 50\% going 1-2 times a quarter or less. Nevertheless, their shopping is purely impulsive, with $70 \%$ of those surveyed buying clothes when they feel the need. As for the type of consumer they identify with, $32.7 \%$ say they buy clothes they like without looking at price or durability, $24.3 \%$ buy a lot of cheap clothes expecting them to last as long as possible, $21.7 \%$ buy few clothes at a low price but expecting them to last longer, $16.9 \%$ buy expensive clothes expecting them to last longer, and $4.9 \%$ buy clothes that are trendy, cheap and have a short life cycle.

Finally, in consumption terms, 67.4\% spend less than 100 euros per month on fashion products and $25.5 \%$ between 100 and 200 euros, while $43.3 \%$ spend less than $5 \%$ on slow fashion products, and $19.6 \%$ between 5 and $10 \%$. These results indicate that the consumers surveyed spend little on fashion products, which could be a problem for adopting a more expensive product such as slow fashion apparel. Furthermore, only $69.3 \%$ have heard of this concept, with the most popular brands being Inditex JoinLife (47.6\%), H\&M's Conscious (46.8\%), Mango's Committed (40.4\%) and Ecoalf (21\%). 
Table 1. Main demographic information.

\begin{tabular}{|c|c|}
\hline Demographic Categories & Frequency $(\%)$ \\
\hline \multicolumn{2}{|l|}{ Gender } \\
\hline Female & 73.8 \\
\hline Male & 25.9 \\
\hline Non-binary & 0.3 \\
\hline \multicolumn{2}{|l|}{ Age (years old) } \\
\hline $18-24$ & 36.3 \\
\hline $25-34$ & 14.2 \\
\hline $35-44$ & 32.6 \\
\hline $45-54$ & 9 \\
\hline $55-64$ & 5.6 \\
\hline $65+$ & 2.2 \\
\hline \multicolumn{2}{|l|}{ Education } \\
\hline Higher education or less & 5.2 \\
\hline Occupational training & 9.4 \\
\hline Bachelor's degree & 21.3 \\
\hline Graduate degree & 35.6 \\
\hline Master's degree & 22.1 \\
\hline Ph.D. degree & 6.4 \\
\hline \multicolumn{2}{|l|}{ Monthly fashion consumption (EUR) } \\
\hline Less than 100 & 67.4 \\
\hline 100-200 & 25.5 \\
\hline 201-300 & 5.2 \\
\hline $301-400$ & 1.1 \\
\hline More than 400 & 0.7 \\
\hline
\end{tabular}

\subsection{Path Analysis}

Path analysis was developed and introduced into the literature in the 1910s and 1920s by the biologist Sewell Wright [50,51]. During all these years, this methodology has been used in various fields such as medicine, psychology, economics, or education, among others. Path analysis is a technique employed to analyze the postulated causal relationships between variables measured at a specific instant in time and therefore its applicability to retrospective or ex post facto research [52]. The importance of this methodology lies in its simplicity and visualization of the causal relationships between variables. Several authors [53] indicate that this method can be considered an extension of the multiple regression model, where not only the direct contribution of a set of independent variables on a dependent variable is verified but also the interaction between the predictor variables and the indirect influence of the predictor variables on the dependent variable [54].

The research model proposed in Figure 1 attempts to establish the causal relationship between slow fashion orientation, customer perceived value, willingness to pay and intention to purchase variables, allowing to test the hypotheses described in Section 2. 


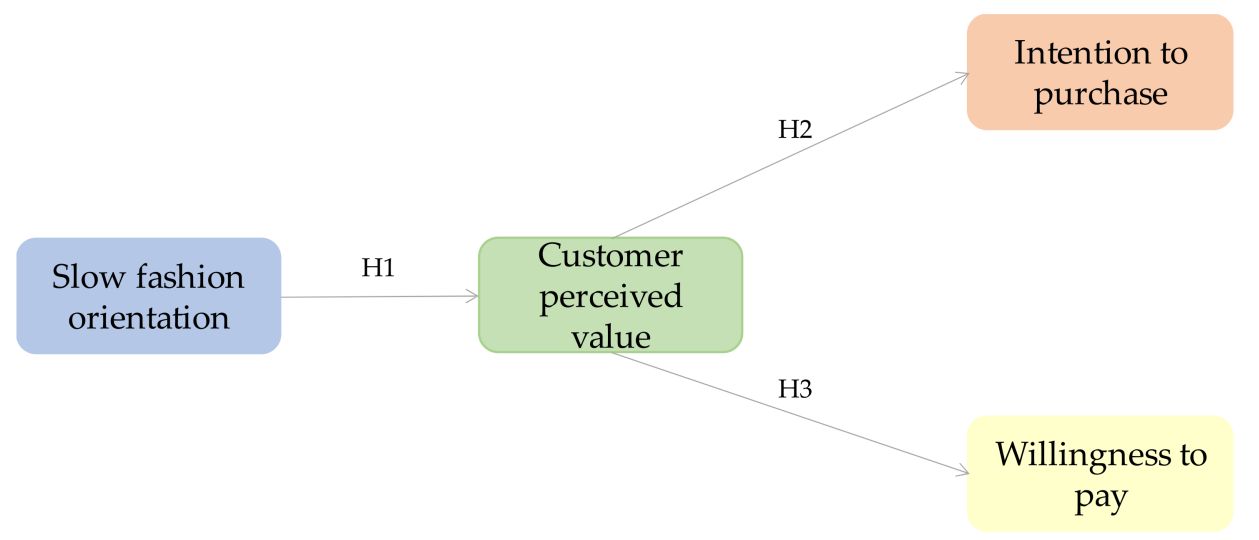

Figure 1. Research model.

\section{Results}

To test the proposed hypothesis, a path analysis was performed. The model includes all the causal relationships proposed in the hypotheses. Additionally, the relationship between slow fashion orientation and intention to purchase was also analyzed since the effects of this orientation are not expected to be completely mediated by perceived value. The overall goodness-of-fit indices point to a good fit of the model to the data (chi-square $=$ 11.25; $\mathrm{CFI}=0.950 ; \mathrm{SRMR}=0.070$ ). The main results are shown in Table 2.

Table 2. Path analysis results.

\begin{tabular}{cccccc}
\hline Hypothesis & $\begin{array}{c}\text { Independent } \\
\text { Variable }\end{array}$ & $\begin{array}{c}\text { Dependent } \\
\text { Variable }\end{array}$ & $\begin{array}{c}\text { Standardized } \\
\text { Coefficient }\end{array}$ & $p$ & $\begin{array}{c}\text { Direct } \\
\text { Effect }\end{array}$ \\
\hline 1 & $\begin{array}{c}\text { Slow fashion } \\
\text { orientation }\end{array}$ & $\begin{array}{c}\text { Perceived } \\
\text { value }\end{array}$ & 0.379 & 0.000 & Supported \\
\hline 2 & $\begin{array}{c}\text { Perceived } \\
\text { value }\end{array}$ & $\begin{array}{c}\text { Intention to } \\
\text { purchase }\end{array}$ & 0.299 & 0.000 & Supported \\
\hline 3 & $\begin{array}{c}\text { Perceived } \\
\text { value }\end{array}$ & $\begin{array}{c}\text { Willingness } \\
\text { to pay more }\end{array}$ & 0.253 & 0.000 & Supported \\
\hline & $\begin{array}{c}\text { Slow fashion } \\
\text { orientation }\end{array}$ & $\begin{array}{c}\text { Intention to } \\
\text { purchase }\end{array}$ & 0.177 & 0.001 & \\
\hline
\end{tabular}

As shown in Table 2, the results underline that there is a direct effect between consumer orientation and perceived value; thus, H1 is supported. Therefore, it confirms the change that society is experiencing toward the circular economy, seeing slow fashion items as products with high added value as they believe that this type of product can contribute to an improvement of the environment. In addition, the results show that there is a significant direct effect between perceived value and intention to purchase. Thus, hypothesis $\mathrm{H} 2$ is also supported. This result indicates that society is changing, and conscious consumers are more predisposed to buy sustainable fashion items, as the benefits for the environment and society are tangible, and through sustainable purchasing, they are contributing to environmental and social improvement. Finally, we analyzed the relation between "perceived value" and "willingness to pay more". The results indicate that the corresponding standardized coefficient reaches the value of $0.253(p<0.01)$. Hence, hypothesis 3 is also supported. This fact confirms the importance of sustainability in fashion products, where those products that meet the standards that characterize a slow fashion product will be better perceived by customers, and they will be willing to pay more to acquire this sustainable product and contribute to the environmental improvement. In addition, we found a significant direct influence of slow fashion orientation on intention to purchase. The effect on intentions is not only produced via a higher perception of the value of the product but also directly. The conscious customer detects a value in the purchase of 
the slow fashion product that goes beyond the perceived value of the product itself. The act of buying the sustainable product itself brings additional value. Figure 2 represents graphically the causal relationships after applying the path analysis.

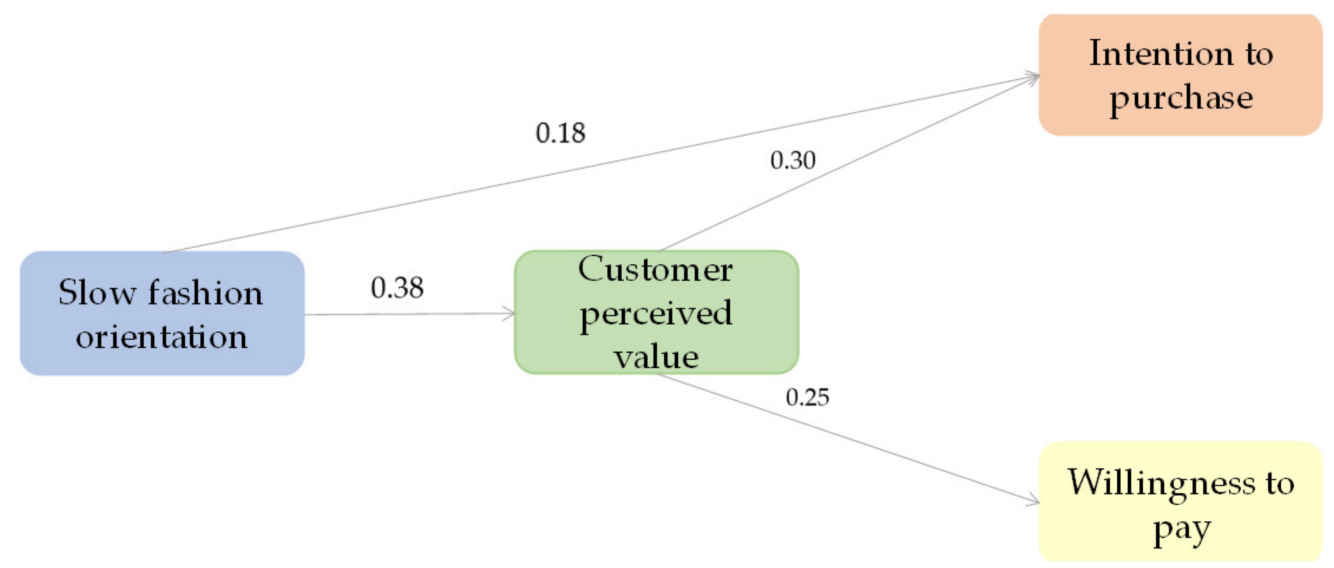

Figure 2. Causal relationships.

\section{Conclusions}

Over the years, and particularly after the rise of prêt-à-porter, the fashion industry has negatively influenced the well-being of the fashion consumer by creating a sense of artificial need, novelty and obsolescence. This is complemented by a linear manufacturing process characterized by an excessive consumption of energy and raw materials and a high production of waste. Currently, the fashion industry is characterized as one of the most polluting industries. Nonetheless, nowadays, an increasing number of consumers are becoming aware of environmental and ethical issues, and they are convinced of protecting the environment and society with their consumption acts. In this way, they are adopting sustainable behaviors when it comes to consuming fashion products. The trend in this sense seems to be growing, and thus the efforts of companies to implement sustainable policies can be rewarded in the short or medium term with regard to profitability.

The results of this study confirm the change in consumer consumption habits. Consumers are increasingly oriented toward sustainable fashion as a tool to preserve the environment and the health and well-being of society and are also willing to pay more for a slow fashion product. Slow fashion consumers are more committed in terms of sustainability, and therefore, when they see a product with these characteristics in the store, they perceive it as having greater value than other fast fashion products that are more harmful in terms of sustainability. Therefore, the perceived value of a sustainable product encourages purchase intent, as consumers believe that by buying this type of product, they are contributing to the improvement of the environment. In fact, consumers' commitment to this new circular economic model is such that they are willing to pay more to buy these types of products because of the benefits they have for society in terms of health, well-being, environmental effects, and contribution to a clean and safe world. In this sense, companies must be aware of the relevance of this new consumption paradigm and adapt their production processes to the new needs of consumers who are more oriented toward environmental and social issues.

The findings of this study support the importance that the new slow fashion trend is having in society. An increasing number of consumers adhere to this new trend that focuses on slowing down the production and consumption processes and promoting sustainable values among all actors involved in the fashion system as a path to improve the environment and the health of society. Hence, these findings give fashion companies a better understanding of the slow fashion movement, the key factors that influence perceived value, how they positively influence purchase intent and how the consumer 
is willing to pay more for this slow fashion product to contribute to the safeguard of the environment and the society's health.

Finally, companies must bear in mind that this new consumer trend might generate important benefits, and although it is difficult to adapt production processes, administrations, institutions, and consumers are willing to help companies to achieve this change. On the one hand, consumers are willing to pay more for a slow fashion product, and, on the other hand, administrations and institutions are providing funding to change production processes from the linear to the circular model. Therefore, companies must act and adapt as soon as possible to this new trend, which, as the results of this study show, is becoming increasingly relevant.

This study is circumscribed to the Spanish market. It would be interesting to make a comparison between different national markets and to determine whether this predisposition to change consumption habits is influenced by the culture of each country. Furthermore, we could outline the relevance of being able to analyze whether this change toward slow fashion tends to be more accepted by empowered people, thus facilitating a quicker growth of this new type of slow consumption.

Author Contributions: Conceptualization, A.C.-L., V.I. and J.P.; Data curation, A.C.-L., V.I. and J.P.; Formal analysis, A.C.-L., V.I. and J.P.; Funding acquisition, A.C.-L., V.I. and J.P.; Investigation, A.C.-L., V.I. and J.P.; Methodology, A.C.-L., V.I. and J.P.; Project administration, A.C.-L., V.I. and J.P.; Resources, A.C.-L., V.I. and J.P.; Software, A.C.-L., V.I. and J.P.; Supervision, A.C.-L., V.I. and J.P.; Validation, A.C.-L., V.I. and J.P.; Visualization, A.C.-L., V.I. and J.P.; Writing—original draft, A.C.-L., V.I. and J.P.; Writing-review \& editing, A.C.-L., V.I. and J.P. All authors have read and agreed to the published version of the manuscript.

Funding: This research was funded by Ministerio de Ciencia e Innovación, Gobierno de España, grant number MCI-20-PID2019-105726RB-I00.

Institutional Review Board Statement: Not applicable.

Informed Consent Statement: Informed consent was obtained from all subjects involved in the study.

Data Availability Statement: Not applicable.

Conflicts of Interest: The authors declare no conflict of interest.

\section{References}

1. Kraaijenhagen, C.; Van Oppen, C.; Bocken, N. Circular business. Collaborate and Circulate. Circular Collaboration, Amersfoort, The Netherland. 2016. Available online: https:/ / www.circularcollaboration.com (accessed on 9 November 2021).

2. Majean, E. The Circular Economy and the Fashion Industry, [L'économie circulaire et l'industrie de la mode]; Universud: Liège, Belgium, 2020.

3. Euratex. Key Figures 2018-The EU-28 Textile and Clothing Industry in the Year 2018. 2019. Available online: https:/ / euratex. eu/facts-and-key-figures/ (accessed on 9 November 2021).

4. Conama. A Vision of the Future for the Textile Sector; Committee Technical Session ST-25, National Environmental Congress; Fundación Conama: Madrid, Spain, 2019.

5. European Commission. Circular Economy Action Plan; Brussels, Belgium. 2020. Available online: https://ec.europa.eu/ environment/pdf/circular-economy/new_circular_economy_action_plan.pdf (accessed on 9 November 2021).

6. Vadakkepatt, G.G.; Winterich, K.P.; Mittal, V.; Zinn, W.; Beitelspacher, L.; Aloysius, J.; Ginger, J.; Reilman, J. Sustainable Retailing. J. Retail. 2021, 97, 62-80. [CrossRef]

7. Pearce, D.W.; Turner, R.K. Economics of Natural Resources and the Environment; JHU Press: Baltimore, MD, USA, 1989.

8. MacArthur, E. Towards a Circular Economy: Business Rationale for an Accelerated Transition; Ellen MacArthur Foundation: Isle of Wight, UK, 2015.

9. Watson, M.Z.; Yan, R. An exploratory study of the decision processes of fast versus slow fashion consumers. J. Fash. Mark. Manag. 2013, 17, 141-159.

10. Fletcher, K. Slow Fashion: An Invitation for Systems Change. Fash. Pract. 2015, 2, 259-265. [CrossRef]

11. Cohen, M.J. Does the COVID-19 outbreak mark the onset of a sustainable consumption transition? Sustain. Sci. Pract. Policy 2020, 16, 1-3. [CrossRef]

12. Degli Esposti, P.; Mortara, A.; Roberti, G. Sharing and Sustainable Consumption in the Era of COVID-19. Sustainability 2021, 13, 1903. [CrossRef] 
13. Paniagua, J.; Rivelles, R.; Sapena, J. Social Determinants of Success: Social Media, Corporate Governance and Revenue. Sustainability 2019, 11, 5164. [CrossRef]

14. Henninger, C.; Alevizou, P.; Oates, C. What Is Sustainable Fashion. J. Fash. Mark. Manag. 2016, 20, 400-416. [CrossRef]

15. Henninger, C.; Alevizou, P.; Goworek, H.; Ryding, D. Sustainability in Fashion: A Cradle to Upcycle Approach; Springer: Berlin/Heidelberg, Germany, 2017.

16. Blazquez, M.; Henninger, C.; Alexander, B.; Franquesa, C. Consumers' Knowledge and Intentions towards Sustainability: A Spanish Fashion Perspective. Fash. Pract. 2019, 12, 34-54. [CrossRef]

17. Shen, B.; Wang, Y.; Lo, C.; Shu, M. The impact of ethical fashion on consumer purchase behavior. J. Fash. Mark. Manag. 2012, 16, 234-245. [CrossRef]

18. Langown, A. Slow fashion as an alternative to mass production: A fashion practitioner's journey. Soc. Bus. 2014, 4, 33-43. [CrossRef]

19. Koszewska, M. Circular economy in textiles and fashion-The role of a consumer. In Circular Economy in Textiles and Apparel; Woodhead Publishing: Sawston, UK, 2019; pp. 183-206.

20. Matušovičová, M. Sustainable fashion as a part of the circular economy concept. Studia Commer. Bratisl. 2020, 13, 215-223. [CrossRef]

21. Hugo, A.D.A.; Nadae, J.D.; Lima, R.D.S. Can Fashion Be Circular? A Literature Review on Circular Economy Barriers, Drivers, and Practices in the Fashion Industry's Productive Chain. Sustainability 2021, 13, 12246.

22. Ertekin, Z.O.; Deniz, A. Sustainable markets motivating factors, barriers, and remedies for mobilization of slow fashion. J. Macromark. 2015, 35, 53-69. [CrossRef]

23. Gupta, S.; Wencke, G.; Gentry, J. The role of style versus fashion orientation on sustainable apparel consumption. J. Macromarketing 2019, 39, 188-207. [CrossRef]

24. Sener, T.; Biskin, F.; Kilinc, N. Sustainable dressing: Consumer' value perceptions towards slow fashion. Bus. Strategy Environ. 2019, 28, 1548-1557. [CrossRef]

25. Jung, S.; Jin, V. Sustainable Development of Slow Fashion Businesses: Customer Value Approach. Sustainability 2016, 8, 540. [CrossRef]

26. Legere, A.; Kang, J. The role of self-concept in shaping sustainable consumption: A model of slow fashion. J. Clean. Prod. 2020, 258, 120699. [CrossRef]

27. Chi, T.; Gerard, J.; Yu, Y.; Wang, Y. A study of US consumers' intention to purchase slow fashion apparel: Understanding the key determinants. Int. J. Fash. Design. Technol. Educ. 2021, 14, 101-112. [CrossRef]

28. Cavender, R.C.; Lee, M.Y.; Wesley, S. The Impact of Slow Fashion Orientation (SFO) on Socially Responsible Apparel Consumption (SRC): Moderating Effects of Industry Irresponsibility and Consumer Irresponsibility. Int. J. Bus. Soc. Sci. 2021, 12, 1-15.

29. Morgan, L.; Birtwistle, G. An Investigation of Young Fashion Consumers' Disposal Habits. Int. J. Consum. Stud. 2009, 33, 190-198. [CrossRef]

30. Harris, F.; Roby, H.; Dibb, S. Sustainability clothing: Challenges, barriers and interventions for encouraging more sustainable consumer behavior. Int. J. Consum. Stud. 2015, 40, 309-318. [CrossRef]

31. Forsman, L.; Madsen, D. Consumers' Attitudes Towards Sustainability and Sustainability Labels in the Fashion Industry; The Swedish School of Textiles, University of Boras: Boras, Sweden, 2018.

32. Khandual, A.; Pradhan, S. Fashion brands and consumers approach towards sustainable fashion. In Fast Fashion, Fashion Brands and Sustainable Consumption; Muthu, S., Ed.; Textile Science and Clothing Technology Springer: Singapore, 2019.

33. Zeithaml, V. Consumer perceptions of price, quality, and value: A means-end model and synthesis of evidence. J. Mark. 1988, 52, 2-22. [CrossRef]

34. Kotler, P.; Armstrong, G. Principles of Marketing, 18th ed.; Prentice Hall: Hoboken, NJ, USA, 2020.

35. Simová, J. Conceptual Models of Customer Value: Implications for Clothing Retailing. EEM Econ. Management $2009,1,88-97$.

36. Sweeney, J.C.; Soutar, G.N. Consumer perceived value: The development of a multiple item scale. J. Retail. 2001, 77, 203-220. [CrossRef]

37. Belk, R.W. Possessions and the extended self. J. Consum. Res. 2018, 15, 139-168. [CrossRef]

38. Pookulangara, S.; Shephard, A. Slow fashion movement Understanding consumer perceptions: An exploratory study. J. Retail. Consum. Serv. 2013, 20, 200-206. [CrossRef]

39. Cavender, R.C.; Lee, M.Y. Exploring the influence of sustainability knowledge and orientation to slow consumption on fashion leaders' drivers of fast fashion avoidance. Am. J. Theor. Appl. Bus. 2018, 4, 90-101. [CrossRef]

40. Gupta, H.; Kumar, A.; Wasan, P. Industry 4.0, cleaner production and circular economy: An integrative framework for evaluating ethical and sustainable business performance of manufacturing organizations. J. Clean. Prod. 2021, 295, 126253. [CrossRef]

41. Anderson, E.; Mittal, V. Strengthening the satisfaction-profit chain. J. Serv. Res. 2016, 3, 107-120. [CrossRef]

42. Ajzen, I. The theory of planned behavior. Organ. Behav. Hum. Decis. Process. 1991, 50, 179-211. [CrossRef]

43. Zheng, Y.; Chi, T. Factors influencing purchase intention towards environmentally friendly apparel: An empirical study of US consumers. Int. J. Fash. Des. Technol. Educ. 2015, 8, 68-77. [CrossRef]

44. Kumar, A.; Prakash, G.; Kumar, G. Does environmentally responsible purchase intention matter for consumers? A predictive sustainable model developed through an empirical study. J. Retail. Consum. Serv. 2021, 58, 102270. [CrossRef] 
45. Chi, T. Consumer perceived value of environmentally friendly apparel: An empirical study of Chinese consumers. J. Text. Inst. 2015, 106, 1038-1050. [CrossRef]

46. Vehmas, K.; Raudaskoski, A.; Heikkilä, P.; Harlin, A.; Mensonen, A. Consumer attitudes and communication in circular fashion. J. Fash. Mark. Manag. Int. J. 2018, 22, 286-300. [CrossRef]

47. Schmidt, J.; Bijmolt, T.H. Accurately measuring willingness to pay for consumer goods: A meta-analysis of the hypothetical bias J. Acad. Mark. 2020, 48, 499-518. [CrossRef]

48. Presley, A.; Meade, L.M. The business case for sustainability: An application to slow fashion supply chains. IEEE Eng. Manag. Rev. 2018, 46, 138-150. [CrossRef]

49. Wang, T.; Wang, J.; Wu, P.; Wang, J.; He, Q.; Wang, X. Estimating the environmental costs and benefits of demolition waste using life cycle assessment and willingness-to-pay: A case study in Shenzhen. J. Clean. Prod. 2018, 172, 14-26. [CrossRef]

50. Blalock, H.M. Causal Inferences in Nonexperimental Research; University of North Carolina Press: Chapel Hill, NC, USA, 1964.

51. Heise, D.R. Employing nominal variables, induced variables, and block variables in path analyses. Sociol. Methods Res. 1972, 1, 147-173. [CrossRef]

52. Duffy, J.R.; Watt, J.; Duffy, R.J. PATH analysis: A strategy for investigating multivariate causal relationships in communication disorders. J. Speech Lang. Hear. Res. 1981, 24, 474-490. [CrossRef]

53. Aron, A.; Aron, E. Stadistics for Pyscology; Pearson Education: Buenos Aires, Argentina, 2001.

54. Pérez, E.; Medrano, L.A.; Rosas, J.S. PATH Analysis: Basics concepts and application. Rev. Argent. Cienc. Comport. 2013, 5, 52-66. 